\title{
Katliamlara Tanıklık: Sanat Eserleri Aracılığı İle Hatırlamak ${ }^{1}$
}

\section{Witnessing The Massacres: Remembering Through The Works of Art}

\section{Serkan Çalıșkan}

Dr. Öğr. Üyesi, Kırklareli Üniversitesi Lüleburgaz Meslek Yüksekokulu Grafik Tasarım Bölümü email: s.serkan.caliskan@gmail.com (DORCID ID: https://orcid.org/0000-0002-1309-4574

${ }^{1} \mathrm{Bu}$ çalışma, 27-29 Nisan 2018 tarihlerinde Budapeşte /Macaristan'da gerçekleşen "IV. Internatıonal Congress on AfroEurasıan Research" adlı sempozyumda sunulmuş özet bildirinin genişletilmiş halidir.

Atıf (APA 6)/To cite this article

Calıșkan, S. (2019). Katliamlara tanıklık: sanat eserleri aracılığı ile hatırlamak. Atatürk Üniversitesi Güzel Sanatlar Enstitüsü Dergisi, 43, 105114. doi: https://doi.org/10.35247/ataunigsed.564681

Makale Gönderim Tarihi/Received: 13/05/2019

Makale Kabul Tarihi/Accepted: 01/10/2019

Makale Yayın Tarihi/Published: 26/10/2019

$\ddot{O} z$

Bu çalışma, tarihte yaşanmış, insan eliyle uygulanan katliamların sanat eserlerine yansıması ve toplumsal hafizayla olan iliskisini araştırmayı amaçlamaktadır. Tarihin akışını değiştiren olaylar yazılı ve sözel tarih aracılığı ile günümüze ulaşırken, sanat eserleri de görsel bellek olarak tarih yazımına katkıda bulunmaktadır. Diğer bir deyişle; savaş resimleri, büstler ve portreler gibi coğaltılabilecek birçok sanat eseri, bir belge olarak tarihsel süreçleri çözümlememize yardımcı olduğu kadar aynı zamanda tarihi sorgulamaya aracilık etmektedir. Hemen hemen her ulusta ya dinsel ya da politik nedenlerle oluşan anlaşmazlıklar sonucunda çıkan savaşlar ya da benzeri şiddet olayları, sanat pratiklerinde karşımıza çıkmaktadır. Yaşanan bu olaylar, farklı dönem ve sanatsal üsluplarla sanat eserleri aracıllı̆̆ ile günümüze kadar ulassmaktadır. İspanyol ressam Francisco Goya'nın 1814 tarihli "Üç Mayıs Katliamı" adlı eseri, Fransız askerlerinin İspanya'ya yaptığı işgalde direnen halkın kurşuna dizilme sahnesini doğrudan göstermesi açısından önemlidir. Katalan ressam Pablo Picasso'nun "Guernica" (1937) adlı eseri İspanya İç Savaşı sırasında Nazi askerlerinin Guernica kasabasını bombalamasını tasvir etmesi ve yaşanan dehșeti izleyiciye göstermesi açısından önemlidir. Yine Pablo Picasso'ya ait olan "Kore Katliamı 1951" adlı eser, Amerikan askerlerinin Kore'deki halka uyguladığ 1 şiddeti görselleştirmesi adına önemlidir. II. Dünya Savaşı ile ilgili diğer bir resim de Zi Jian Li'nin “Büyük Nanjing Katliamı” adlı eseridir. II.Dünya Savaşı'nda Japonların Çin'in Nanjing eyaletinde yaklaşık üç yüz bin kişinin öldürdüğü "Büyük Nanjing Katliamı" olarak anılan olayları, savastan yıllar sonra Li'nin eserinde görmek mümkündür. Sanatçı 1992 yılında ürettiği resimde, birçok figür aracıllı̆ı ile ceset "dağı” resmederek, tarihte yaşanmış bu olayın dramatik ölçüsünü gözler önüne sermektedir. Savaşlar ve şiddetin çok sık yaşandığı Ortadoğu'da 1982 yılında İsrail yanlısı Hristiyan milisleri tarafindan gerçekleşen ve "Sabra ve Şatilla Katliamı" olarak anılan olayda, aşırı sağcılar Filistin mülteci kampına saldırmıș ve içlerinde çocukların da olduğu yüzlerce kişiyi öldürmüslerdir. Dia alAzzawi'nin 1982-83 yıllarında olayın ardından ürettiği "Sabra ve Satilla Katliamı" adlı eseri, 300 x $750 \mathrm{~cm}$ boyutuyla, yaşanan katliamın arkasından yakılan bir ağıt gibi durmaktadır. Verilen bu örneklerin dışında, günümüz sanatında da katliamlara yönelik eserler bulunmaktadır. Bununla birlikte, günümüz sanatının ontolojik yapısı gereği, sanatçılar katliamları doğrudan göstermek yerine, yaşanan olayları hatırlatmaya yönelik anlatı dili seçmeleri, bu eserleri diğerlerinden ayıran bir özellik olarak dikkat çekicidir. Can Togay ve Gyula Pauer tarafindan yapilan "Tuna Ayakkabıları" (2005), Budapește'de Tuna Nehri kenarında yaşanan olaya tanıklık etmemizi sağlayan anıtsal bir heykeldir. Aslına uygun 60 adet metal ayakkabıdan olusan bu eser, II. Dünya Savaş1 sırasında Nazi askerleri tarafindan nehir kenarında ayakkabıları çıartılarak kurșuna dizilerek öldürülen binlerce Yahudi anısına yapılmıștır. Yine günümüz sanatından bir örnek olarak, Güney Afrikalı sanatçı Haroon Gunn'ın 2018 tarihli "Senzenina" adlı eseri tarihsel tanıklık adına önemli bir eserdir.
Zulu ve Xhosa dilinde "Ne Yapmıştık" anlamına gelen bu eserde, 2012 Ağustos'unda Marikana'da (Güney Afrika) platin madeninde grev yapan madencilerin, polis tarafindan silahla öldürülmesi konu edilmektedir. Olay sırasinda ölen 34 madencinin savunmasız bir şekildeyken öldürülmesi, enstalasyon aracılığı ile izleyiciye aktarılmaktadır.

Anahtar kelimeler: Katliam, Soykırm, Sanat

\section{Abstract}

This study aims to research the reflection of human-made massacres in the history on the works of art and its relationship with the social memory. While the events that change the course of history are conveyed through written and verbal history, the works of art also contribute to the writing of history as visual memory. In other words, many works of art such as war paintings, busts and portraits help us to analyze historical processes as a document and enable to question the history as well. Wars or similar events of violence, which have occurred in almost every nation due to conflicts for religious or political reasons, are also reflected in the practice of art. These events have reached the present day with different periods and artistic styles thanks to the works of art. The Spanish painter Francisco Goya's "The Third of May" (1814) is important in that it shows the scene where people who resisted the French occupation of Spain were executed. The Catalan painter Pablo Picasso's work "Guernica" (1937) is important within the context of depicting the bombing of Guernica by Nazi soldiers during the Spanish Civil War and shows the audience the horror that took place. Also, Pablo Picasso's another work entitled "Massacre in Korea, 1951" is important as it visualizes the violence committed by American soldiers against the people in Korea. Another painting about the World War II is Zi Jian Li's Great Nanjing Massacre. It is possible to see in Li's works many years after the war the events called "Great Nanjing Massacre" where the Japanese killed about three hundred thousand people in Nanjing province of China during the World War II. In his work of 1992, the artist depicts a "mountain" of corpses using many figures, revealing the dramatic magnitude of this event that took place in the history. In the event called "Sabra and Shatila Massacre", which committed by pro-Israeli Christian militias in 1982 in the Middle East, a region of frequent wars and violence, the extreme rightists attacked the Palestinian refugee camp and killed hundreds of people, including children. The work that Dia al-Azzawi created between 1982-83 after the incident, entitled "Sabra and Shatila Massacre", is like a mourning for the massacre with its size of $300 \times 750 \mathrm{~cm}$. Besides these examples, there are works of art related to massacres in the contemporary art. However, due to the ontological structure of today's art, it is an interesting feature that distinguishes these works from others that artists prefer a narrative language to recall the events experienced, rather than portraying the massacres directly. Can Togay and Gyula Pauer's "Shoes on the Danube 
Bank" (2005) is a monumental sculpture that helps us witness the event that took place on the banks of Danube River in Budapest. Consisting of 60 metal shoes true to their originals, this work was created in honor of thousands of Jews who were ordered to take off their shoes and shot and killed by Nazi soldiers during the Second World War. As an example of contemporary art, South African artist Haroon Gunn's "Senzenina" of 2018 is an important work for witnessing the history. Meaning "What Have We Done?" in Zulu and Xhosa language, this work portrays the killing of miners who went on a strike in platinum mine in Marikana (South Africa) in August 2012 by the police. The killing of 34 miners who died in the incident is conveyed to the audience through the installation art.

Keywords: Massacres, Genocide, Art

\section{Giris}

İnsanlık tarihi boyunca birçok katliam ve soykırım meydana gelmiştir. Bu dramatik şiddet olayları, tarihsel kaynaklar aracılığı ile günümüze kadar ulaşmaktadır. Bu çalışmada tarihte yaşanmış büyük soykırım ve katliamlar ele alınmaktadır. Öncelikli olarak katliam ve soykırım kavramlarının sözlük açıklamasına bakıldığında, bu iki kavramın birbirinden farklı olduğu görülmektedir. Dar bir tanımla katliam, aynı anda ya da belli zaman aralığında birçok insanın biri veya gruplar tarafından öldürmesidir. Soykırım ise belli bir etnik veya dinsel gruba yapılan, kökten yok etme eylemlerini kapsamaktadır. Yine bu kavramlara bağlı olarak ifade edilebilecek yok etme eylemleri vardır, bunlar: Genosit, jenosit ve pogromdur.

Geçmiş yüzyıla bakıldığında birçok katliam ve soykırım örneğini görmek mümkündür. Örneğin; İkinci Dünya Savaşı sırasında Yahudilere yönelik uygulanan soykırım, tarihteki en dramatik olaylar arasındadır. Yaklaşık altı milyon Yahudi, birçok Avrupa ülkesinde insanlık dışı işkence yöntemleri uygulanarak katledilmiştir. Yine İkinci Dünya Savaşı sırasında Amerikan ordusunun Japonya'ya attığı atom bombalarıyla yüzbinlerce insanın ölmesine sebep olmuş, büyük bir katliamdır. İkinci Dünya Savaşı haricinde, resmi olarak soykırım olarak adlandırılan katliamlar, 1980'ler sonrasında sömürge devletlerinde karşımıza çıkmaktadır. Örneğin, Afrika kıtasında birçok katliam ve soykırım yaşanmıştır. 1994 yılında Afrika kıtasında bulunan Ruanda'da yaşanan katliam da bunlardan biridir. Ruanda' daki soykırımda 1994 yılında yaklaşık bir milyon Tutsi katledilmiştir. Buna benzer kıyımlar Afrika kıtasının farklı ülkelerinde de yaşanmıştır: 1989-2003 yılları arasında Afrika kıtasında Liberya'da yaşanan iç savaşta on binlerce insan ölmüştür. 1990'ların sonlarında Sierra Leone'de yaşanan iç savaşta binlerce kişi yaşamını yitirmiştir. Uganda, Çad ve Sudan'da da benzer etnik çatışmalar meydana gelmiş ve birçok kişi yaşamını yitirmiştir. Sovyet Rejimi'nin dağılması ve değişen dünya dinamikleriyle birlikte Balkanlar'da başlayan savaşta da binlerce kişi katledilmiştir. Srebrenista Katliamı olarak bilinen soykırımda: "1995 yılında 11 ve 22 Temmuz tarihleri arasında Sırp Cumhuriyet Ordusu ve paramiliter Akrep birlikleri tarafindan gerçekleştirilen katliamda 8 bin 373 Müslüman öldürüldü’ (Gazete Duvar, 2017).

Bu çalışmada, yukarıda açıklanmaya çalışılan katliam, soykırım ve şiddet olgusunun yarattığı travmalar ve bu travmaların sanat eserlerine yansıması incelenmektedir. Diğer bir ifadeyle, bu çalışma, geçtiğimiz yüzyılda ve yakın tarihte yaşanmış dramatik olayları sanat eserleri aracılığı ile hatırlamanın önemi üzerine düşünmeyi hedeflemektedir. Çalışmaya destek vermesi adına yakın tarih dışında Francisco Goya'nın eserine yer verilmiştir. Buna ek olarak Pablo Picasso'nun çalışmaları da, daha sonra değinilecek çalışmalara referans olmasına önemli bir örnek olduğu için çalışmaya dahil edilmiştir. Makalede de Zi Jian Li'nin (1954) "Büyük Nanjing Katliamı" adlı eseri, Uzak Doğu'dan bir örnek olması, orada yaşananları hatırlatması ve Batı sanatından farklı bir yerde durma adına önemli bulunmuş ve çalışmaya dahil edilmiştir. Dia al-Azzawi'nin 1982-83 yıllarında olayın ardından ürettiği "Sabra ve Şatilla Katliamı" adlı eseri, Orta Doğu'da bitmeyen şiddetin tanıklı̆̆ı ve hatırası olarak önemlidir. Can Togay ve Gyula Pauer tarafindan yapılan "Tuna Ayakkabıları" (2005), Budapeşte'de Tuna Nehri kenarında duran anıtsal bir heykeldir ve İkinci Dünya Savaşı sırasında Budapeşte'de yaşanan dramatik Yahudi ölümlerini izleyiciye hatırlatmaktadır ve bu bilgiyi taşımaktadır. Güney Afrikalı sanatçı Haroon Gunn'ın 2018 tarihli "Senzenina" adlı eseri yine tarihsel tanıklık adına önemli bir eserdir. Zulu ve Xhosa dilinde "Ne Yapmıştık" anlamına gelen bu eserde, 2012 Ağustos'unda Marikana'da (Güney Afrika) platin madeninde grev yapan madencilerin, polis tarafından silahla öldürülmesi konu edilmektedir.

\section{Yöntem}

$\mathrm{Bu}$ araştırma Betimsel modele dayalı nitel bir araştırmadır. Araştırmada öncelikli olarak literatür taraması yapılmış ve veri toplanmışıtır. Katliam, soykırım kavramları etimoloji sözlüklerinden yararlanılarak açıklanmaya çalışılmıştır. Sonrasında da dünya genelindeki büyük katliamlar incelenmiş ve ortak özellikleri araştırılmıştır. Tüm bunlara bağlı olarak katliam ve soykırım üzerine çalışan sanatçıların çalışmalarına odaklanılmış, aralarından bazı eserler elenerek son halini almıştır. Metinde kullanılan eserler, bağlamına göre sınıflandırılırken aynı zamanda kronolojik metotla sınıflandırılma yapılmıştır. Eserler incelenirken, temel nitelikli sanat tarihi kitapları ve konuyla ilgili makaleler incelenmiş̧ir. Yine eser seçiminde 1960 sonrası çeşitli eserlere odaklanılmıştır. Fakat konuyu desteklemesi amacıyla Francisco Goya ve Pablo Picasso gibi daha erken dönem sanatçıların katliam üzerine üretmiş olduğu eserler de ele alınmıştır. Bununla birlikte, etimoloji sözlüğü, gazete haberleri, süreli 
yayınlar, katliam ve soykırımlar hakkında yayınlanmış kitaplar incelenerek, sanat tarihindeki eserlerle ilişkilendirilmesine katkıda bulunmuştur.

\section{Bulgular}

\subsection{Bir şiddet biçimi olarak katliamlar ve soykırımlar}

Katliamlar, insanlık tarihi boyunca birçok toplumun tanık olduğu dramatik şiddet olaylarını kapsayan eylemlerdir. Dar bir tanımla katliam, aynı anda ya da belli zaman aralığında birçok insanın biri veya gruplar tarafindan öldürmesidir. $\mathrm{Bu}$ tanıma, doğaya ve hayvanlara yönelik toplu yok etme eylemleri de eklenebilir. Kavram etimolojik olarak incelendiğinde sözcügüun köken olarak Arapça'dan Türkçe’ye geçtiği görülmektedir. Toplu öldürme anlamına gelen kelime, katil ve kamu/halk köklerinin birleşmesinden oluşmaktadır (Nisanyan Sözlük, 2019). Türk Dil Kurumu'nun açıklamasında ise "kırım” olarak nitelendirilen katliamlar, bir topluluğun diğer bir topluluğa doğrudan şiddet uygulayarak öldürmesi ve/veya yok etmeye dayalı amaç barındıran olayların tümünü nitelemektedir. Bu açıklama da katliamların soykırım ve etnik temizlik ile yakın ilişkisini vurgulamaktadır. Bu açıklamalar bağlamında, soykırım kavramını incelemek de önemlidir. Türk Dil Kurumu'na göre soykırım: isim, toplum bilimi, bir insan topluluğunu ulusal, dinsel vb. sebeplerle yok etme, jenosit, genosit, pogrom (TDK, 2019). Türk Dil Kurumu'nun soykırım için yaptığı tanım, katliam ve soykırım arasındaki farkı açıkça belirtmektedir. Her ne kadar kavramlar iç içe geçmiş gibi görünse de arada kritik bir çizgi vardır; katliam toplu yok etme eylemi iken, soykırım belli nedenlerle (din, dil, etnik vb.) bir topluluğu yok etmeye dayalı eylemleri kapsamaktadır.

Bu açıklamalar 1şı̆̆ında geçtiğimiz yüzyıla bakıldığında hem katliamlar hem de soykırımlar adına olumsuz birçok örnek meydana geldiği görülmektedir. Örneğin; İkinci Dünya Savaşı sırasında Yahudilere yönelik uygulanan soykırım, tarihteki en dramatik olaylar arasındadır. Yaklaşık altı milyon Yahudi, birçok Avrupa ülkesinde insanlık dışı işkence yöntemleri uygulanarak katledilmiştir. Yine İkinci Dünya Savaşı sırasında Amerikan ordusunun Japonya'ya attığı atom bombalarıyla yüzbinlerce insanın ölmesine sebep olmuş, büyük bir katliamdır. (Bu iki örnek, daha önce açıklanmaya çalışılan katliam ve soykırım kavramları arasındaki farkı da vurgulaması nedeniyle önemlidir.) Savaş sonrasında Birleşmiş Milletler Kurulu 1949 yılında Fransa/Paris’te gerçekleşen toplantısında, ister savaş ortamı olsun ister olmasın soykırımın bir suç olduğuna dair bir dizi karar almıştır. Toplantıda alınan kararlar soykırım tanımlanması açısından önemlidir. Karara göre:

Madde 2- Bu Sözleşme bakımından, ulusal, etnik, ırksal veya dinsel bir grubu, kısmen veya tamamen ortadan kaldırmak amacıyla işlenen aşağıdaki fiillerden herhangi biri, soykırım suçunu oluşturur. a. Gruba mensup olanların öldürülmesi. b. Grubun mensuplarına ciddi surette bedensel veya zihinsel zarar verilmesi. c. Grubun bütünüyle veya kısmen, fiziksel varlığını ortadan kaldıracağı hesaplanarak yaşam şartlarını kasten değiştirmek. d. Grup içinde doğumları engellemek amacıyla tedbirler almak. e. Gruba mensup çocukları zorla başka bir gruba nakletmek (BM, 1949, s. 33).

Birleşmiş Milletler Kurulu'nun kararına rağmen dünyanın birçok noktasında savaşlar, çatışmalar, iş savaşlar ve katliamlar meydana gelmiştir. Bu katliamların birçoğu, henüz soykırım olarak tanınmamıştır. Resmi olarak soykırım olarak adlandırılan katliamlar, 1980'ler sonrasında sömürge devletlerinde karşımıza çıkmaktadır. 1980’lerde dünya ekonomik sisteminin dönüşmeye başlaması ile küreselleşme hız kazanıp, gelişmemiş ve gelişmekte olan bölgelere nüfuz etmeye başlamıştır (Çoban Öztürk, 2014, s. 105). Bu dönüşümlere bağlı olarak Afrika kıtasında birçok katliam ve soykırım yaşanmıştır. 1994 yılında Afrika kıtasında bulunan Ruanda'da yaşanan katliam da bunlardan biridir. Ülkede 1994 yılında 20. Yüzyılın en büyük ve en acımasız katliamlardan biri yaşanmıştır. İç savaş sırasında ülke yönetiminde bulunan Hutular, Hutu çoğunluğun da desteğini alarak, yaklaşık bir milyon Tutsi ve 1lımlı Hutuyu katletmiştir (Çoban Öztürk, 2014, s. 15). Buna benzer kıyımlar Afrika kıtasının farklı ülkelerinde de yaşanmıştır: 1989-2003 yılları arasında Afrika kıtasında Liberya'da yaşanan iç savaşta on binlerce insan ölmüştür. 1990'ların sonlarında Sierra Leone'de yaşanan iç savaşta binlerce kişi yaşamını yitirmiştir. Uganda, Çad ve Sudan'da da benzer etnik çatışmalar meydana gelmiş ve birçok kişi yaşamını yitirmiştir. Sovyet Rejimi'nin dağılması ve değişen dünya dinamikleriyle birlikte Balkanlar'da başlayan savaşta da binlerce kişi katledilmiştir. Srebrenista Katliamı olarak bilinen soykırımda: 1995 yılında 11 ve 22 Temmuz tarihleri arasında Sırp Cumhuriyet Ordusu ve paramiliter Akrep birlikleri tarafından gerçekleştirilen katliamda 8 bin 373 Müslüman öldürüldü (Gazete Duvar, 2017).

Bununla birlikte katliamlar belli gruplar arasında olmanın dışında da karşımıza çıkmaktadır. Çeşitli ideolojik nedenler gerekçe gösterilerek belli gruplara şiddet uygulandığı, hatta bu şiddetin dozunun arttığı gerginliklerde katliam olarak nitelendirilecek olaylara da tanık olmaktayız. Bu çalışmada, yukarıda açıklanmaya çalışılan katliam, soykırım ve şiddet olgusunun yarattığı travmalar ve bu travmaların sanat eserlerine yansıması incelenmektedir. Diğer bir ifadeyle, bu çalışma, geçtiğimiz yüzyılda ve yakın tarihte yaşanmış dramatik olayları sanat eserleri aracılığg ile hatırlamanın önemi üzerine düşünmeyi hedeflemektedir. 


\subsection{Sanat aracılığı ile katliamları hatırlamak}

Sanat, tarih boyunca birçok katliama, savaşa ve soykırıma tanıklık etmiştir. Bu tanıklık, bazı sanatçıların doğrudan sanat ürünlerine yansımıştır. Örneğin iki büyük dünya savaşı arasında, Avrupa sanatında savaşın yarattığı gerginlik hissedilmekte ve sanatçıların eserlerine yansımaktadır. Max Beckman, Otto Dix ve George Grosz gibi sanatçıların eserlerinde savaş karşıtı duruş, toplumların yozlaşması ve savaşın dramatik etkisini görmek mümkündür. Bu sayede, yıllar sonra savaşı ve şiddeti izleyici ile buluşturur sanatçılar ve bu durum, görsel belleğe dair izler barındığı gibi, diğerlerinin tanıklığını da açığa çıkarır. Susan Sontag savaş fotoğrafları ve daha fazlası hakkında yazdığı Başkalarının Acısına Bakmak adlı kitabında şöyle demektedir: Bir cehennemi göstermek, elbette insanların o cehennemden nasıl çıkarılacağı, cehennem ateşinin nasıl söndürüleceği konusunda herhangi bir şey anlatmaz bize. Yine de, başkalarıyla paylaştığımız şu dünyada, bazı insanların, insanların kötücüllüğü ve sapkın yanlarının ne denli 1stıraplara yol açtığını bilmesi ve bu konuda görüşlerini derinleştirmesi kendi içinde hala olumludur (Sontag, 2004, s. 114). Savaş atmosferinde veya savaştan yıllarca sonra üretilmiş eserleri birer iletişim aracı olarak görmek de mümkün olabilir. Diğer yandan savaşın yarattığı karamsar hisler, sanatçılar tarafindan gösterilmeye ihtiyaç duyulan duygulardır. Acıların ikonografisinin uzun bir geçmişi, deyiş yerindeyse bir soyağacı vardır. Gösterilmeye değer sayılan acılar, kaynağı ister ilahi güçler, isterse insanoğlu olsun, bir gazabın sonucu olarak kavranan acilardır (Sontag, 2004, s. 39).

Günümüz iletişim araçları çokça olanağa sahip olduğu için, dünyanın herhangi bir noktasında olan, meydana gelen olaylar saniyeler içerisinde tüm dünyaya yayılabilmektedir. Bu bilgiler (yazılı veya görsel) gelecek nesillere aktarılacaktır. Geleneksel tarih yazıcılığı ve arşivciliği görevini yaparken, gelecek nesiller algoritmalar ve datalar sayesinde çok fazla bilgiye ulaşabilecektir. İletişim olanaklarının günümüzdeki gibi olmadığı bir çağda yaşanan olaylar ise bizlere, tarih ve sözlü tarih aracılığı ile ulaşmaktadır. Bilim olarak tarih, bilgiyi arşivlemesi ve sınıflandırması adına çok önemlidir. Sözlü tarih ise geleneksel tarih anlayışının kapsadığı olayların dışından bakan alternatif bir tarihsel araçtır. Toplumların hatırlaması ve gerçekleşen olaylara dair hatıraları nesiller aracılığı ile aktarması ile oluşmaktadır.

Bununla birlikte, hatırlamak ve tarih kavramları sıklıkla birlikte kullanılsa da, bu iki kavram arasında farklılıklar vardır. Nora’ya (2006, s. 19) göre: Tarih sıralı, biçimli, ayrıştırıcı ve kurallı olarak zihinsel bir süreç olarak işlerken, hafıza ise duygulara dayalı olarak sırasız, kuralsız, karışık ve sürekli gelişim halinde karşımıza çıkar. Nora'nın açıklaması bağlamında sanat eserlerinin diğer bir tarihsel araç olarak hatırlatıcı nesne olduğu söylenebilir. Diğer bir ifadeyle, sanat eserlerinin toplumsal hafıza ile ilişkisi olduğu söylenebilir. Sanat eserleri tarihsel anlatıdan bağımsız da ele alınabilir olması açısından ve yine farklı bir belge olarak günümüze ulaşmaları bakımından önemlidir. Sanat eserleri; olayların nasıl geliştiği, neler olduğuna dair bilgilerden daha farklı olarak, sanatçının olaya bakış açısını da ortaya koymaktadır. Geçmişte yaşanan olayları dinamik bir şekilde günümüze kadar taşırken, Sontag'ın da dediği gibi, izleyicinin başkalarının yaşadığı 1stırapları görmesi ve derinlemesine düşünmesi adına katkı sağlaması önemlidir. $\mathrm{Bu}$ açıklamalar bağlamında, tarih boyunca yaşanmış katliamların sanat tarihi aracılı̆̆ı ile hatırlamanın önemli olduğu açıktır.

İspanyol ressam Francisco Goya'nın 1814 tarihli ve günümüzde Madrid Prado Müzesi'nde sergilenen “Üç Mayıs Katliamı" (Üç Mayıs 1808 olarak da bilinmektedir) adlı eserde, Fransız askerlerinin İspanya'ya yaptı̆̆g işgalde direnen halkın kurşuna dizilme sahnesini doğrudan göstermektedir. Goya, bu resimde olayları aktarırken dolambaçlı yollar kullanmamıştır. Doğrudan göstermek istediği imgeyi izleyiciye aktarmıştır. Başka bir deyişle, eser bir tür fotoğraf gibidir ve bir anın ölümsüzleştirildiği görülmektedir. Kompozisyonu oluşturan ana unsur, askerler tarafından kurşuna dizilen figürün etrafındaki olay örgüsünden inşa edilmiştir. Yerdeki fenerin yaydığı 1şık, figürleri ve (aslında) olayı aydınlatmakta veya açığa çıkarmaktadır. Kurbanların yaşadığı korku ve endişe ortaya çıkmaktadır. Cebrail Ötgün makalesinde Goya’nın çalışmasını şu şekilde açıklamaktadır:

Goya şiddetin kaynağının otoriteye, güce ve militarizme ait olduğunu belirtmekte ve eleştirel bir tavır sergilemektedir. Kompozisyon karşıtını birlikte sunan ve bundan dolayı etkisini arttıran ikili planlar üzerine kuruludur. Bu planlar durağanlık-hareket, açık-koyu gibi sayılabilir. Durağanlık koyu, hareket açık alanda verilmiştir. Ayrıca anlam olarak da resim, ezen-ezilen(ölen-öldürülen), ölüm-yaşam gibi karşıt kavramları da çıkarmaktadır. Resimde şiddetin yorumu güçlü bir doğa gözleminin sonucudur (Ötgün, 2008, s. 94).

$\mathrm{Bu}$ açıklamalar dışında, sanatçının eseri, yazılı tarihin sunduğu sınırlı bilginin ötesinde de bir bilgi taşımaktadır. Bir görüntü aracılığı ile yaşanan dramın gözler önüne serilmesine olanak sağlamaktadır. Bu olanak, asla kaçamayacağız, unutmak istesek de unutamayacağımız acının görselleşmesidir. 


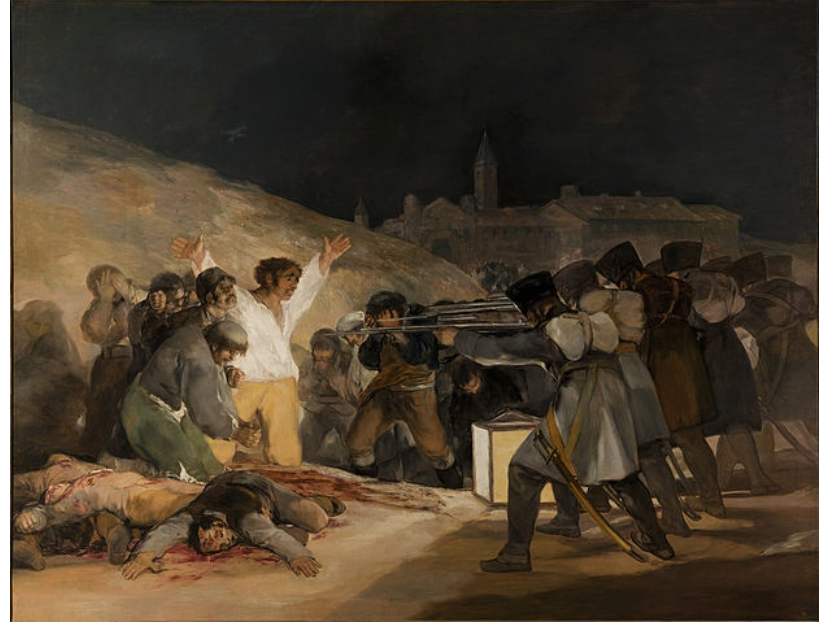

Görsel 1. Francisco Goya, Üç Mayıs Katliamı, 1814, 2.68 x 3.47 m. tuval üzerine yağlı boya.

Katalan sanatçı Pablo Picasso da, Goya'nın eserinde olduğu gibi yıllar sonra İspanya'ya yapılan bir saldırıyı resmetmiştir. 26 Nisan 1937'de Nazi askerleri tarafından sabaha karşı bombalanan Guernica kasabasını konu edinen ressam, 3.5 × 7.8 metrelik epey büyük ölçülü bir tuvale bu resmi üretmiştir. Resim yalnızca siyah beyaz renkler içermektedir. Resimde, savaşın korkunç yüzü yerine, doğrudan kurbanların yaşadığı dehşet gösterilmektedir. İspanya'yı simgeleyen boğa, ölmüş yetişkin ve kucağında bebekle çığlık atan bir kadın o karanlıkta yaşanan dramı, siyah beyaz zıtlığı ve figürlerin dramatik jestleriyle anlatmaktadır. Yine Picasso'ya ait "Kore Katliamı 1951" adlı eseri, savaş ve katliam ilişkisini gösteren önemli bir örnektir. İkinci Dünya Savaşı sonrası değişen dünya dinamiklerinden çok da kopuk olmayan Uzakdoğu'daki savaşlar ve Kore Savaşı büyük katliamlara tanıklık etmiştir. Picasso da bu savaşın ve yaşanan katliamların etkisini göstermektedir. Savaş süresinde ABD ordusu Sinchon kentini işgal etmiştir. Ekim 1950'de başlayan işgal birkaç ay sürmüş ve otuz beş bin sivil çeşitli işkencelerle öldürülmüştür. Sanatçının bu çalışmada yukarıda da bahsedilen Goya'nın Üç Mayıs Katliamı adlı çalışmasına bir gönderme yapmaktadır. Kurbanlar insan görünümündeyken, katliamı yapanlar robotumsu bir kitleyi andıran görüntüdeki figürlerdir. Bu açıdan bakıldığında da Picasso'nun her iki eseri de hatırlatma ve toplumsal belleğe katkısı adına önemli örnekler olduğu açıktır. Çünkü bellek, daha önce de değinildiği gibi, kişisel olabildiği kadar kolektif de olabilmektedir. Atik ve Bilginer Erdoğan toplumsal kolektif belleğin önemi şu şekilde açıklamaktadırlar:

Bellek, geçmişten gelen birikimlerin diğer kuşaklara aktarılmasılyla anlam kazanır. Geçmişle gelecek arasındaki köprü olan ve şimdinin içinde yaşadığı yer bellektir. Bellek sadece zihinsel bir işlev olmaktan ziyade içinde yaşadığımız şu anda bulunmaktadır. Bellek, bir kişinin münferit olarak hatırlayabildiği anıların yaşadığı zihinsel bir ambar olarak görülebilir. Aynı şekilde toplumların da geçmişlerinde önemli rol oynayan tarihsel, sosyal, kültürel, ekonomik vs. olayların kolektif bir bellek etrafından yeniden zuhur etmesiyle toplumsal bellekten söz etme ihtiyacı doğar (Atik ve Bilginer Erdoğan, 2014, s. 2).

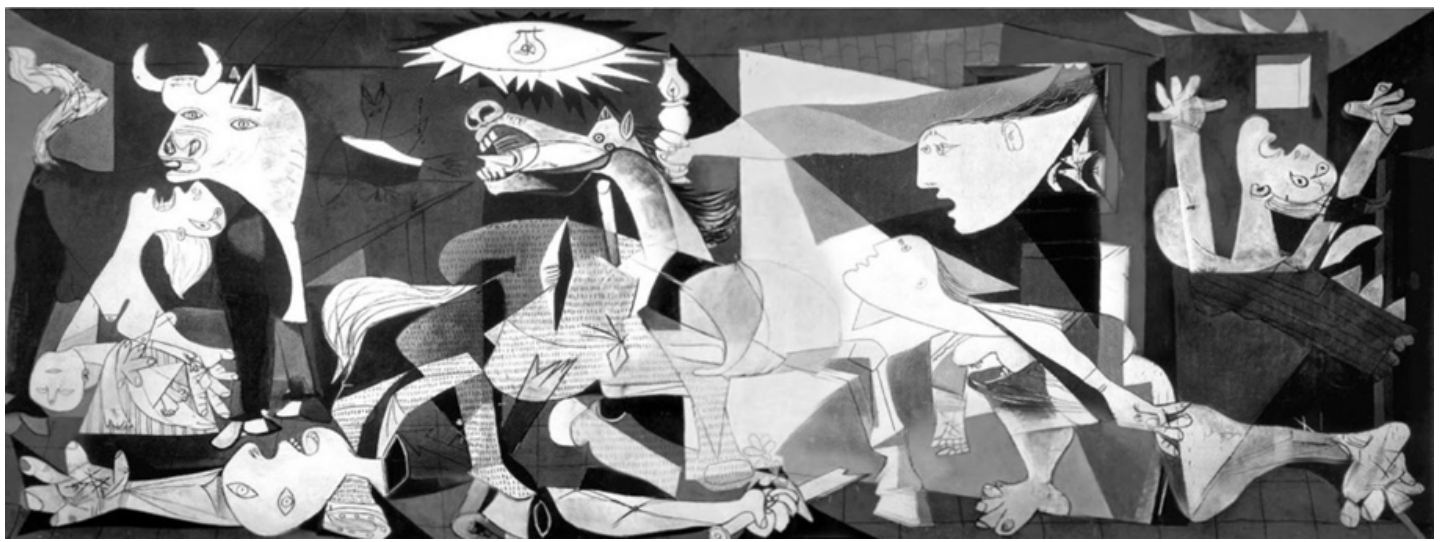

Görsel 2. Pablo Picasso, Guernica, 1937, 3.49 x 7.77 m. tuval üzerine yağlı boya 


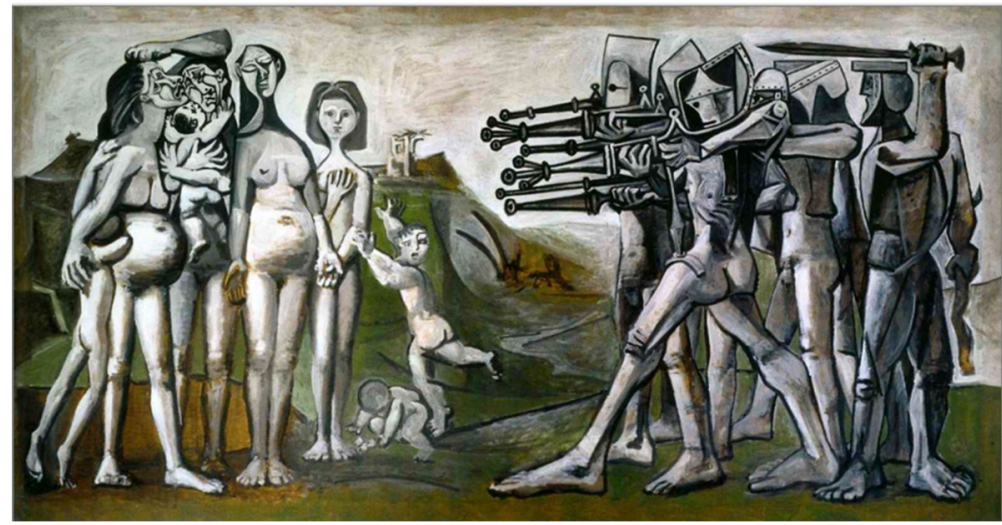

Görsel 3. Pablo Picasso, Kore Katliamı 1951, 1951, 1.1 x 2.1 m. tuval üzerine yağlı boya

II. Dünya Savaşı ile ilgili diğer bir resim de Zi Jian Li’nin (1954) “Büyük Nanjing Katliamı” adlı eseridir. II.Dünya Savaşı'nda Japonların Çin'in Nanjing eyaletinde yaklaşık üç yüz bin kişinin öldürdüğü "Büyük Nanjing Katliamı" olarak anılan olayları, savaştan yıllar sonra Li'nin eserinde görmek mümkündür. Sanatçı 1992 yılında ürettiği resimde, birçok figür aracıllğı ile ceset "dağı" resmederek, tarihte yaşanmış bu olayın dramatik ölçüsünü gözler önüne sermektedir. Nanjing eyaletinde yaşanan ve yaklaşık altı hafta süren katliam, sanatçının eserinde savaşın korkuları, trajedi, vahşeti yansıtır niteliktedir. Li'nin yaşanan bu dehşet verici katliam için bir farkındalık yaratmayı hedeflediği söylemek mümkündür ve kurbanların unutulan tarihine bir saygı gösterisi olarak düşünülebilir. Sanatçının Global Times gazetesine yaptı̆̆ı röportajda, resminin üç bölüme ayrıldığını ifade etmekte ve ayrılan bölümlerin anlamlarını şu şekilde açıklamaktadır: Tu: (katliam), sheng (yeni hayat) ve fo (Buda). Dört rakam çizdim: Sol altta iki Japon askeri katliamı temsil ediyor, ağlayan çocuk ceset dağının tepesinde ölü annesinin kollarından sürünerek yeni bir hayat ve sağ altta yer alan Budist rahip ölü bedenleri topluyor ve Buda'yı sembolize ediyor. Anneler çocuklarının kollarından tutuyor, kız kardeşler de en son dakikaya kadar ellerini tutuyor (Tingting, 2017). Bu bağlamda, sanatçının eserinde unutma, hatırlama, kolektif bellek kavramları ve yaşanan şiddetin izlerini, çeşitli semboller ve doğrudan ceset yığınları aracıllığı ile görmek mümkündür.

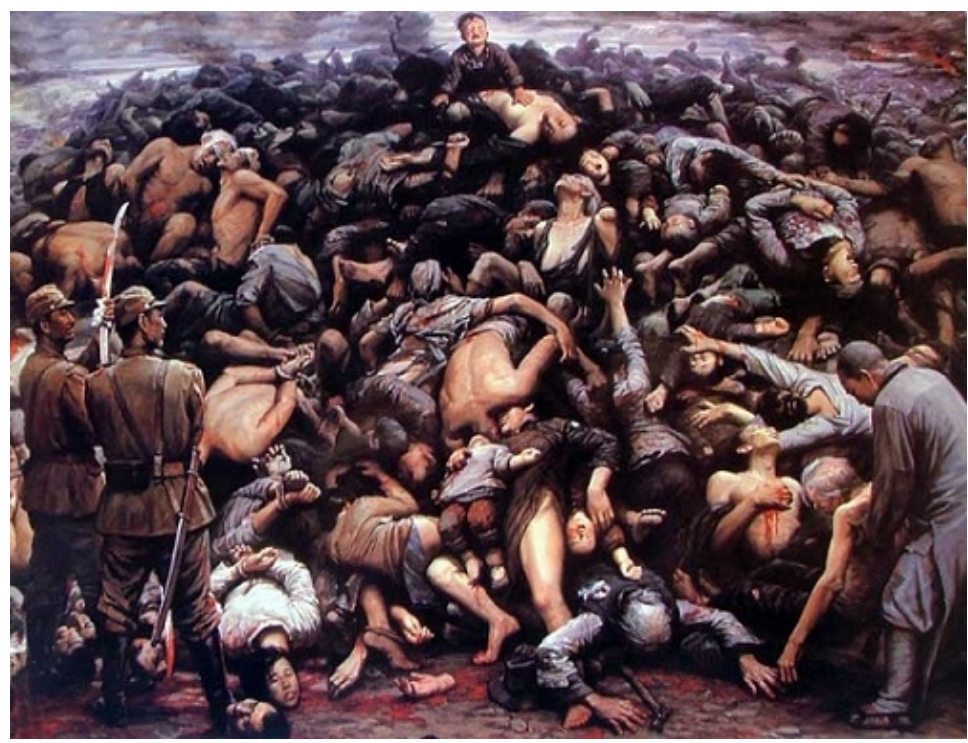

Görsel 4. Zi Jian Li, Nanjing Katliamı, 1992, 213 x 290 cm tuval üzerine yağlı boya

Savaşlar ve şiddetin çok sık yaşandığı Ortadoğu'da 1982 yılında İsrail yanlısı Hristiyan milisleri tarafindan gerçekleşen ve "Sabra ve Şatilla Katliamı" olarak anılan olayda, aşırı sağcılar Filistin mülteci kampına saldırmış ve içlerinde çocukların da olduğu yüzlerce kişiyi öldürmüşlerdir. Dia al-Azzawi'nin 1982-83 yıllarında olayın ardından ürettiği "Sabra ve Şatilla Katliamı" adlı eseri, 300 x $750 \mathrm{~cm}$ boyutuyla, yaşanan katliamın arkasından yakılan bir ağıt gibi durmaktadır. Altı parçadan oluşan tuvalin üzerine yapıştırılmış kağıtlara tükenmez kalem, yağlı pastel boya ile oluşturulan eser, boyutu dışında da taşıdığı bağlam nedeniyle anıtsal bir değer taşımaktadır. Stilize, deforme edilmiş insan ve hayvan figürleri, bombalar ve şiddete dair diğer semboller yaşanan vahşeti açı̆ğa çıkarmaktadır. Sanatçının eseri Picasso'nun Guernica tablosuyla da paslaştığı görülmektedir. İki eser arasındaki plastik benzeşmenin dışında, şiddet ve vahşet görüntüsünde de benzerlikler bulunmaktadır. Bununla birlikte sanatçının eseri üretmeye iten gücü anlamada, Tate Modern küratörüne yaptığı açıklamada net bir şekilde ortaya koymaktadır: 
27 Nisan 2011'de Tate küratörü Jessica Morgan ile konuşan sanatçı, katliamın sahnelerini açıklama kararının, Fransız yazar Jean Genet'in (1910-1986) “Quatre Heures Chatila (Shatila'da Dört Saat) adlı makalesini okuyarak ilham aldığını belirtti. Genet, katliamlar gerçekleştiğinde Beyrut’taydı ve daha sonra kamplara giren ilk gözlemcilerden biriydi. Şöyle yazdı: "Bir fotoğraf sinekleri ve kalın beyaz ölüm kokusunu göstermez. Bir cesetten diğerine doğru yürürken bedenlerin üstünden nasıl atlamanız gerektiğini de göstermez. Orada barbar bir parti vardı (Morgan, 2011).

Sanatçının Genet'in yazısından etkilenerek başladığı çalışması yaşanan vahşeti açığa çıkarmaktadır. Bir köşeden bomba bırakarak gelen uçak, dikenli teller, öylece duran sandalyeler, resmin nerede başladığı ve nerede bittiğinin belirsizliği ile tuvalin içine ve karanlığına gömülmüş figürler, bir tür labirente hapsolmuş gibidir.

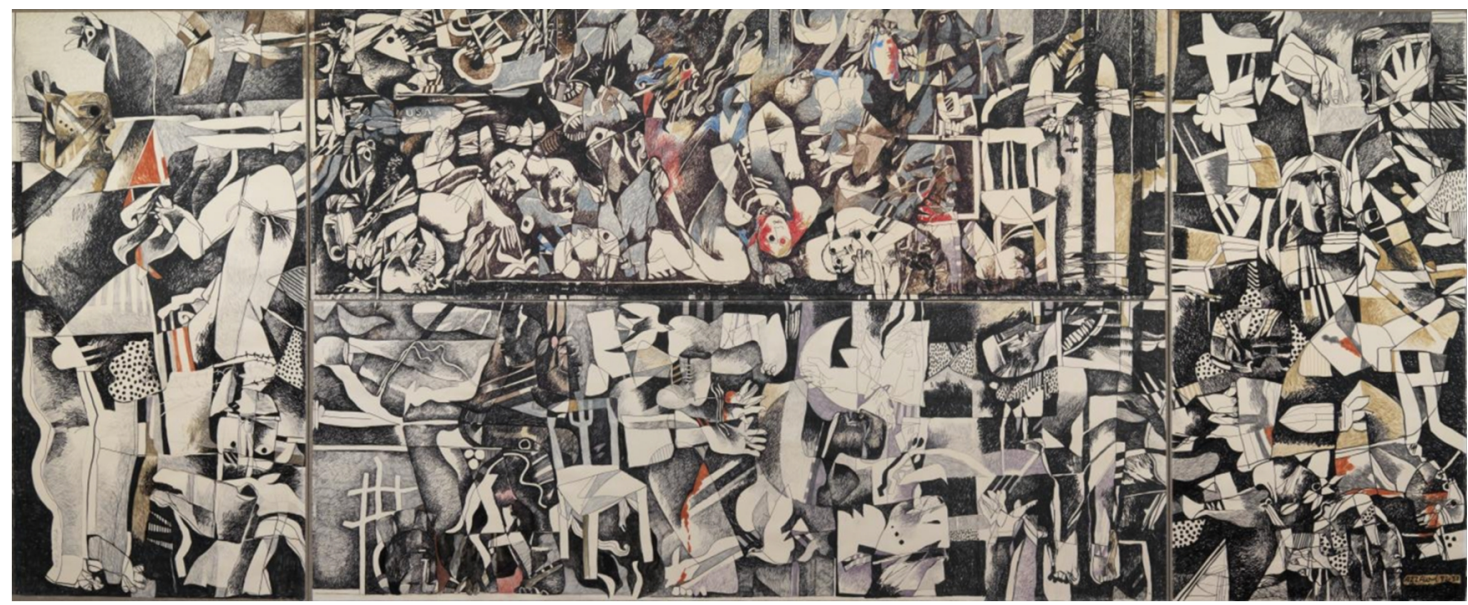

Görsel 5. Dia al-Azzawi, Sabra ve Şatilla Katliamı, 1982-1983, 300 x 750 cm, tuval üzerine karışık teknik

Günümüz sanatının ontolojik yapısı gereği, sanatçılar katliamları doğrudan göstermek yerine, yaşanan olayları hatırlatmaya yönelik anlatı dili seçmeleri, bu eserleri diğerlerinden ayıran bir özellik olarak dikkat çekicidir. Can Togay ve Gyula Pauer tarafından yapılan “Tuna Ayakkabıları” (2005), Budapeşte'de Tuna Nehri kenarında yaşanan olaya tanıklık etmemizi sağlayan anıtsal bir heykeldir. Anıt boyunca üç noktada Macarca, İbranice ve İngilizce “1944-1945'te Arrow Cross milisleri tarafindan vurulup Tuna'ya atılan kurbanların anısina. 16 Nisan 2005 tarihinde kuruldu. ” yazısı bulunmaktadır. Aslına uygun 60 adet metal ayakkabıdan oluşan bu eser, II. Dünya Savaşı sırasında Nazi askerleri tarafından nehir kenarında ayakkabıları çıkartılarak kurşuna dizilerek öldürülen binlerce Yahudi anısına yapılmıştır. Macaristan'da 1944-1945 yılları arasında Nazi yanlısı milisler tarafından yaklaşık seksen bin Yahudi temerküz kamplarına gönderilirken, yaklaşık yirmi bin Yahudinin ise Budapeşte'de öldürüldüğü bilinmektedir. Savaşın karanlık yüzünü hatırlatan bu eser ise yaşananları günümüze taşıyarak, hatırlatma, bellek kavramlarını da izleyiciye sorgulatmaktadır. Soğuk kış gününde nehir kenarına getirilen kurbanlar, son anlarını yaşarken ayakkabılarını çıkarmalarına dair aldıkları emirle ayakkabılarını çıkarırlar, çünkü o ayakkabılar daha sonra kullanılabilecek kadar değerlidir. Kendi canlarından bile daha değerli ayakkabıları arkalarında bırakarak kurşuna dizilen kurbanlar için yapılan bu heykel de kurbanların anısına hala orada durmakta ve yaşanan dramın, çaresizliğin hissini izleyiciye aktarmaktadır. Sherly Silver Ochayon, "Bir Trajedinin Seremonisi" adlı yazısında, yaşanan dehşeti tanıkların da ağzından anlatarak en son eserin etkisine şu şekilde değinir:

Anıt çok etkili çünkü nehir boyunca uzanan dokunaklı, ayakkabılı ayakkabılar boş bırakılmışlar ve sahipleri olmadan bizi şu soruyla yüzleşmeye zorlamaktadırlar: kimin ayakkabılarıydı? Heykelden eksik olan insanlar kimdi? Ayrıca, ayakkabıların her biri farklıdır. Bazılarının yıpranmış topukluları, bazılarının eski püskü üstleri var; bazılarının bağları var, bazılarının açık bıraktığı kayışlar var; bazıları klasik kadın topuklu ayakkabıları, diğerleri ise işçi botları; bazıları dümdüz duruyor, diğerleri düşmüş, aceleyle çıkarılmış gibi. Ve sonra çocukların küçük ayakkabıları var. Bütün bu farklı ayakkabılar nehir kenarlarında öldürülen farklı Yahudileri temsil ediyor. Bu anıtın mahremiyeti çarpıcı ve dokunaklı. Ayakkabılar öyle somuttur ki, onları giyen, ayakları onları şekillendiren, öldürülmeden önce çıkarmaya zorlanan insanları hayal etmek hiç zor değildir. Her ayakkabının bir kişiliği var; her birinin, onu giyen ayağın damgası var. Eksik olan tek şey sahibi. Ayakkabılar, sahiplerinin yüzlerine benzer bir şey geliştirmemize yardımcı oluyor - yüzleri kirlenmiş olanlar- onları istatistiklerden donukluğundan çıkarıp canlı, nefes alan insanlara çeviriyor. Bize bunların insan olduğunu hatırlatıyorlar. Uzun ömürlü, yaşam dolu, macera dolu veya can sıkıntısı çeken, zengin veya sıradan hayatlar yaşamış olabilirler, ancak öldürülene kadar yaşadılar (Ochayon, 2018, s. 1). 


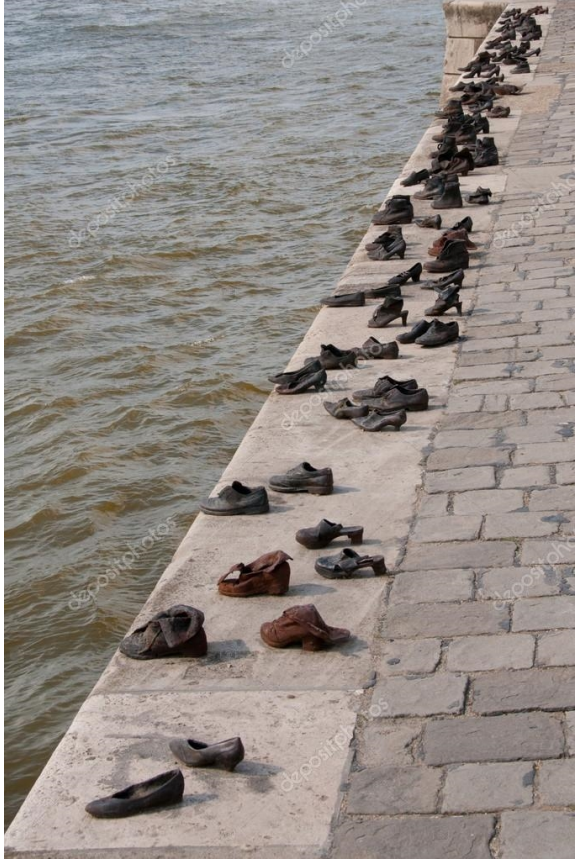

Görsel 6. Can Togay- Gyula Pauer, 2005“Tuna Ayakkabıları”, 60 çift demir ayakkab1.

Yukarıda da değinilen savaşa dair katliamların dışında bir tür katliam olarak bu çalışmaya dahil edilen ve diğerlerinden farklı bir yerde duran ve yine bir katliam sayılabilecek bir eser daha bulunmaktadır. Güney Afrikalı sanatçı Haroon Gunn'ın 2018 tarihli "Senzenina” adlı eseri tarihsel tanıklık adına önemli bir eserdir. Zulu ve Xhosa dilinde "Ne Yapmıştık" anlamına gelen bu eserde, 2012 Ağustos'unda Marikana'da (Güney Afrika) platin madeninde grev yapan madencilerin, polis tarafindan silahla öldürülmesi konu edilmektedir. Olay sırasında ölen 34 madencinin savunmasız bir şekildeyken öldürülmesi, enstalasyon aracılığı ile izleyiciye aktarılmaktadır. Sanatçı kendi çalışması için şunu demektedir: Bence eserin önemi ile yaşanan öykünün ilgisi ve Marikana katliamından topluca alınabilecek derslerden daha az olduğunu düşünüyorum. Çalışmanın niyeti, bu hikâyeyi küresel olarak takdir edilebilecek ve rezonans edebilen fiziksel ve görsel, deneysel bir dil biçiminde göstermektir (Harris, 2018). Şiddetin sanata yansıması nasıl olmalıdır? Doğrudan dehşet anı mı temsil edilmeli yoksa metaforlardan mı destek alınmalı? Sanatçı aslında tüm bunların dışında, ölenleri yeniden bedenlendirerek hatırlatmayı seçmektedir. Kafaları olmayan, bir şeyler anlatmaya veya aramızda olduklarını, unutulmadıklarını, bu dramın dünyanın herhangi bir noktasında her an olabileceğini hatırlatır vaziyette öylece oturmaktadırlar. Tıpkı "Tuna Ayakkabıları" gibi, kafamızı çevirsek de orada duran tarihi unutmamamızı sağlamaktadır.

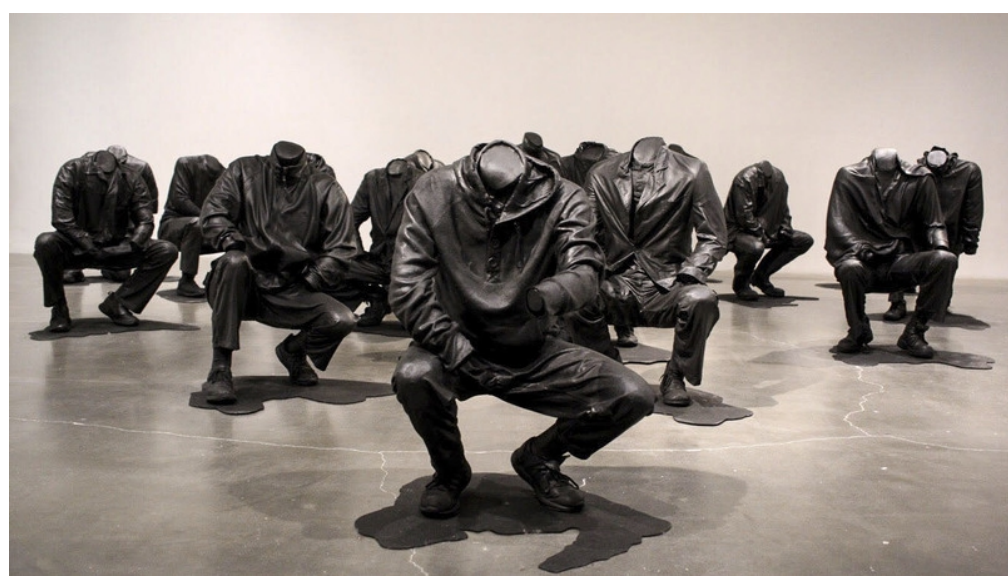

Görsel 7. Haroon Gunn “Senzenina”, 2018, enstalasyon.

\section{Sonuc}

Katliamlar, insanlık tarihi boyunca birçok toplumun tanık olduğu dramatik şiddet olaylarını kapsayan eylemlerdir. Dar bir tanımla katliam, aynı anda ya da belli zaman aralığında birçok insanın biri veya gruplar tarafindan öldürmesidir. Sanat, tarih boyunca birçok katliama, savaşa ve soykırıma tanıklık etmiştir. Bu tanıklık, bazı sanatçıların doğrudan sanat ürünlerine yansımıştır. Örneğin iki büyük dünya savaşı arasında, Avrupa sanatında savaşın yarattığı gerginlik hissedilmekte ve sanatçıların eserlerine yansımaktadır. Max Beckman, Otto Dix ve 
George Grosz gibi sanatçıların eserlerinde savaş karşıtı duruş, toplumların yozlaşması ve savaşın dramatik etkisini görmek mümkündür. Bu sayede, yıllar sonra savaşı ve şiddeti izleyici ile buluşturur sanatçılar. Ve bu durum, görsel belleğe dair izler barındığı gibi, diğerlerinin tanıklığını da açığa çıkarır. Bu çalışmada, savaşın ve katliamların doğrudan gösterildiği ya da katliamların ardından anma amaçlı üretilen eserler incelenmiştir. Bu bağlamda sanatsal yapıtlar incelendiğinde, Goya'nın savaş ve savaşın dehşetini yansıttığı baskı resimleri ve yağlı boya resimleri dikkat çekicidir. Bu çalışmada incelenen İspanyol ressam Francisco Goya'nın 1814 tarihli ve günümüzde Madrid Prado Müzesi’nde sergilenen "Üç Mayıs Katliamı” adlı eserde, Fransız askerlerinin İspanya'ya yaptı̆̆ işgalde direnen halkın kurşuna dizilme sahnesini doğrudan göstermektedir. Çalışma kapsamında ele alınan bir diğer sanatçı Pablo Picasso'dur. Sanatçının Naziler tarafindan bombalanan Guernica kentinde yaşanan dramı ve vahşeti gösterdiği Guernica adlı resmi, hatırlatma ve bellek adına önemli bir örnektir. Yine sanatçının İkinci Dünya Savaşı ardından Uzakdoğu'da yaşanan kuşatmalar, bombalamalar ve katliamlara yönelik ürettiği "Kore Katliamı 1951" adlı eseri, ABD ordusun Sinchon kentini 1950 Ekim'inde başlayan ve birkaç ay süren kuşatmasında otuz beş bin sivilin çeşitli işkencelerle öldürülmesine yönelik bir eleştiri olarak görülebilir. Sanatçı bu çalışmasında Goya'nın Üç Mayıs Katliamı adlı çalışmasına bir gönderme yapmaktadır. Kurbanlar insan görünümündeyken, katliamı yapanlar robotumsu bir kitleyi andıran görüntüdeki figürlerdir. II. Dünya Savaşı’nda Japonların Çin'in Nanjing eyaletinde yaklaşık üç yüz bin kişinin öldürdüğ̈ "Büyük Nanjing Katliamı” olarak anılan olayları, savaştan yıllar sonra Zi Lian Li’nin eserinde görmek mümkündür. Sanatçı 1992 yılında ürettiği resimde, birçok figür aracılığı ile ceset "dağg” resmederek, tarihte yaşanmış bu olayın dramatik ölçüsünü gözler önüne sermektedir. Nanjing eyaletinde yaşanan ve yaklaşık altı hafta süren katliam, sanatçının eserinde savaşın korkuları, trajedi, vahşseti yansıtır niteliktedir. Li'nin yaşanan bu dehşet verici katliam için bir farkındalık yaratmayı hedeflediği söylemek mümkündür ve kurbanların unutulan tarihine bir sayg1 gösterisi olarak düşünülebilir. Değişen sosyo ekonomik yapı ve dünya dinamikleri bağlamında, savaşların merkezi haline gelen Ortadoğu, birçok katliama tanıklık etmiştir. 1982 yılında İsrail yanlısı Hristiyan milisleri tarafından gerçekleşen ve "Sabra ve Şatilla Katliamı" olarak anılan olayda, aşırı sağcılar Filistin mülteci kampına saldırmış ve içlerinde çocukların da olduğu yüzlerce kişiyi öldürmüşlerdir. Dia al-Azzawi’nin 1982-83 yıllarında olayın ardından ürettiği "Sabra ve Şatilla Katliamı” adlı eseri, 300 x $750 \mathrm{~cm}$ boyutuyla, yaşanan katliamın arkasından yakılan bir ağıt gibi durmaktadır. Altı parçadan oluşan tuvalin üzerine yapıştırılmış kağıtlara tükenmez kalem, yağlı pastel boya ile oluşturulan eser, boyutu dışında da taşıdığı bağlam nedeniyle anıtsal bir değer taşımaktadır. Bununla birlikte sanatçının eseri üretmeye iten gücü anlamada, Tate Modern küratörüne yaptığı açıklamada net bir şekilde ortaya koymaktadır. Bu çalışmada değinilen resimler dışında iki heykellerden oluşan enstalasyon örneğine de yer verilmiştir ve bu eserler, savaşın dramatik yanını doğrudan göstermenin dışında, hatırlatan birer anıt görevi üstlenmesi açısından dikkat çekicidir. Bunlardan ilki Can Togay ve Gyula Pauer' in ortak çalışması olan "Tuna Ayakkabıları" adlı eserdir. Aslına uygun altmış adet metal ayakkabıdan oluşan bu eser, II. Dünya Savaşı sırasında Nazi askerleri tarafından nehir kenarında ayakkabıları çıkartılarak kurşuna dizilerek öldürülen binlerce (yaklaşık yirmi bin) Yahudi anısına yapılmıştır. Soğuk kış gününde nehir kenarına getirilen kurbanlar, son anlarını yaşarken ayakkabılarını çıkarmalarına dair aldıkları emirle ayakkabılarını çıkarırlar, çünkü o ayakkabılar daha sonra kullanılabilecek kadar değerlidir. Kendi canlarından bile daha değerli ayakkabıları arkalarında bırakarak kurşuna dizilen kurbanlar için yapılan bu heykel de kurbanların anısına hala orada durmakta ve yaşanan dramın, çaresizliğin hissini izleyiciye aktarmaktadır. Bu bağlamdaki diğer örnek ise, savaş dışında bir katliamı bizlere hatırlattığı, gösterdiği için dikkat çekicidir. Güney Afrikalı sanatçı Haroon Gunn'ın 2018 tarihli “Senzenina” adlı eseri tarihsel tanıklık adına önemli bir eserdir. Zulu ve Xhosa dilinde "Ne Yapmıştık" anlamına gelen bu eserde, 2012 Ağustos'unda Marikana'da (Güney Afrika) platin madeninde grev yapan madencilerin, polis tarafından silahla öldürülmesi konu edilmektedir. Olay sırasında ölen 34 madencinin savunmasız bir şekildeyken öldürülmesi, enstalasyon aracılığı ile izleyiciye aktarılmaktadır. Tüm bu açıklamalar ışığında, sanatın yaşamdan çok kopuk bir alanda durmadı̆̆ı, sanatçıların yaşadı̆̆ı çağa ve dramlara tanıklıklarını sanat eserleri aracılığı ile aktarmasının ne kadar önemli olduğu açıktır. Sanatın, tarih biliminin dışında tarihi farklı bir perspektiften aktaran bir araç olduğu da görülmekte ve belleğin görsel bir dille izleyiciye aktarmasının önemini göstermektedir.

\section{Kaynakça}

Atik, A., \& Bilginer Erdoğan, Ş. (2014). Toplumsal bellek ve medya, Atatürk Illetişim Dergisi, 6(14), 1-16.

BM. (1949). Birleşmiş Milletler Soykırım Sözleşmesi. Erişim Adresi: https://www.ombudsman.gov.tr/contents/ files/32702-Soykirim-Sucunun-Onlenmesine-Ve-Cezalandirilmasina-Dair-Sozlesme.pdf

Çoban Öztürk, E. (2014). Ruanda'da trajedi, adalet ve uzlaşma. C. Tüzün (Ed.), 20. yüzyılda soykırım ve etnik temizlik (s. 13-59) içinde. İstanbul: İstanbul Bilgi Üniversitesi Yayınları.

Çolak, F. G. (2014). Büyük Afrika savaşları: Kongo katliamları. C. Tüzün (Ed.), 20. yüzyılda soykırım ve etnik temizlik (s. 95-124) içinde. İstanbul: İstanbul Bilgi Üniversitesi Yayınları.

Gazete Duvar. (2017). Erişim adresi: https://www.gazeteduvar.com.tr/dunya/2017/03/14/srebrenitsakatliaminda-ne-olmustu/ 
Harris, G. (2018, 16 Ağustos). Haroon Gunn-Salie's Senzenina. The Art Newspaper. Erişim adresi: https://www.theartnewspaper.com/news/frieze-sculpture-piece-marks-sixth-anniversary-of-south-africanmining-massacre

Morgan, J. (2011, 27 Nisan). Sabra and Shatila massacre 1982-3. Tate. Erişim adresi: https://www.tate.org.uk/art/artworks/al-azzawi-sabra-and-shatila-

Nişanyan Sözlük. (2019). Katliam. Erişim adresi: http://www.nisanyansozluk.com/?k=katliam

Nora, P. (2006). Hafiza Mekanları. (M. E. Özcan, Çev.). Ankara: Dost Kitabevi.

Ochayon, S. S. (2018). The shoes on the Danube Promenade-commemoration of the tragedy [Blog yazısı]. Erişim adresi: https://www.yadvashem.org/articles/general/shoes- on-the-danube-promenade.html

Ötgün, C. (2008) Sanatın şiddeti ve sınırları. Gazi Üniversitesi Sanat ve Tasarım Dergisi, 1(1), 90-103.

Sontag, S. (2004). Başkalarının acısına bakmak. (O. Akınhay, Çev.). İstanbul: Agora Kitaplığı.

TDK. (2019). Katliam. Erişim adresi: http://www.tdk.gov.tr/index.php?option=com_gts\&arama=gts\&guid= TDK.GTS.5b158a1f962e93.36259224

Tingting, H. (2017, 13 Aralık). An interview with “The Nanjing Massacre” painter Li Zijian. Global Times. Erişim adresi: http://www.globaltimes.cn/content/1080087.shtml

\section{Görsel Kaynakçası}

Görsel 1. Goya, F. (Sanatçı). (1814). Üç Mayıs Katliamı [Yağlı boya]. Erişim adresi: http://www.jdperon.gov.ar/ 2018/06/59-aniversario-de-los-fusilamientos-de-junio-de-1956/

Görsel 2. Picasso, P. (Sanatçı). (1937). Guernica [Yağlı boya]. Erişim adresi: https://tr.wikipedia.org/wiki/ Guernica_(tablo)

Görsel 3. Picasso, P. (Sanatçı). (1951). Kore Katliamı [Yağlı boya]. Erişim adresi: https://www.pablopicasso .org/massacre -in-korea.jsp\#prettyPhoto[image1]/0/

Görsel 4. Lİ, Z. J. (Sanatçı). (1992). Nanjing Katliamı [Yağlı boya]. Erişim adresi: http://doraartgallery.blogspot. com/2011/05/great-nanjing-massacre-zi-jian-li-1992.html

Görsel 5. Al-Azzavi, D. (Sanatçı). (1982-83). Sabra ve Şatilla Katliamı [Karışık Teknik]. Erişim adresi: https://www.tate.org.uk/art/artworks/al-azzawi-sabra-and-shatila-massacre-t14116

Görsel 6. Togay, C. Pauer, G. (Sanatçı). (2005). Tuna Ayakkabıları [Heykel]. Erişim adresi: https://st.depositphotos.com/2684711/3235/i/950/depositphotos_32353825-stock-photo-jewish-memorialbudapest.jpg

Görsel 7. Gunn, H. (Sanatç1). (2018) Senzinina [Heykel ve enstalasyon]. Erişim adresi: https://cs.mg. co.za/crop/content/images /2018/02/22/cow42xX5TncUhRp 9YpqI_Harron_unnamed .jpg/800x 450/ 